\title{
Evaluasi terapi gangguan kantung empedu pada anjing Pomeranian dengan diagnosis penunjang ultrasonografi
}

\author{
Rili Wahyu Aji ${ }^{1, *}$, Deni Noviana ${ }^{2,3}$ \\ ${ }^{1}$ Ilmu Biomedis Hewan, Sekolah Pascasarjana, Institut Pertanian Bogor, Bogor \\ ${ }^{2}$ Departemen Klinik Reproduksi dan Patologi, Fakultas Kedokteran Hewan, Institut Pertanian Bogor, Bogor \\ ${ }^{3}$ Rumah Sakit Hewan Pendidikan, Fakultas Kedokteran Hewan, Institut Pertanian Bogor, Bogor
}

\begin{abstract}
ABSTRAK: Prevalensi gangguan pada kantung empedu anjing adalah 53\% dapat berupa mucocele gallbladder, biliary sludge, dan cholelithiasis. Kasus gangguan tertinggi pada kantung empedu anjing adalah biliary sludge yang dapat didiagnosa lebih lanjut dengan ultrasonografi (USG). Studi kasus ini merupakan rangkuman dari kasus anjing ras Pomeranian usia 9 tahun datang dengan keluhan mengalami muntah frekuen yang dirujuk ke Rumah Sakit Hewan Pendidikan, Fakultas Kedokteran Hewan, Institut Pertanian Bogor. Pemeriksaan USG dilakukan untuk meneguhkan diagnosa. Sonogram menunjukkan permukaan kantung empedu yang tidak rata dan adanya endapan yang menutupi hampir $75 \%$ luas kantung empedu. Anjing tersebut diberikan terapi antimuntah, asam ursodeoxycholic dan hepatoprotektan. Terapi asam ursodeoxycholic dan hepatoprotektan diberikan selama 2-3 bulan dan dievaluasi dengan USG. Hasil evaluasi pertama setelah terapi selama 45 hari terjadi pengurangan endapan menjadi $70 \%$. Hasil evaluasi kedua dari terapi selama 45 hari adalah endapan pada kantung empedu tersisa sebanyak 50\%. Hasil evaluasi ketiga setelah 3 bulan terapi, endapan pada kantung empedu sudah berkurang hingga tersisa kurang dari 30\%. Terapi dihentikan selama 10 bulan dan dilakukan evaluasi terhadap endapan di kantung empedu. Hasil evaluasi terakhir didapatkan adanya peningkatan endapan kantung empedu sebanyak $70 \%$. Berdasarkan hasil evaluasi, anjing tersebut diberikan terapi asam ursodeoxycholic dan hepatoprotektan untuk di konsumsi selama 45 hari.
\end{abstract}

Kata kunci:

anjing, kantung empedu, biliary sludge, mucocelle gall bladder, asam ursodeoxycholic.

\section{- PENDAHULUAN}

Penyakit pada kantung empedu anjing meliputi biliary sludge, mucocele gallbladder, dan batu pada kantung empedu (cholelitiasis) (Mizutani et al. 2017). Diagnosa kelainan pada kantung empedu dapat dilakukan menggunakan diagnosa penunjang utrasonografi (USG). Evaluasi struktur interna kantung empedu dilakukan dengan pemeriksaan USG. Dinding kantung empedu dalam keadaan normal memiliki permukaan yang rata, tipis, ekhogenitas hiperekhoik. Sonogram bagian dalam kantung empedu pada pemeriksaan USG adalah anekhoik dan tidak ada debris. Sonogram mucocele gallbladder adalah terdapat garis-garis hiperekhoik dalam material padatan hipoekhoik. Sonogram biliary sludge adalah tekstur hiperekhoik tanpa adanya acoustic shadowing (Sochi et al. 2012). Sonogram cholelithiasis adalah struktur hiperekhoik dengan acoustic shadowing. Cholelithiasis terbentuk dari biliary sludge yang berukuran lebih dari $1 \mathrm{~mm}$ (Cook et al. 2016).

\section{- METODE}

Hewan dilakukan pemeriksaan fisik, kemudian dilakukan pencukuran pada bagian ventral abdomen. Hewan diposisikan dorsal recumbency. Pemeriksaan USG menggunakan probe linear dengan frekuensi 5-7 MHz. Penilaian sonogram kantung empedu meliputi ketebalan dinding kantung empedu, ukuran kantung empedu, dan ekhogenitas isi kantung empedu. Terapi pemberian sediaan asam ursodeoxycholic dan hepatoprotektan. Evaluasi terapi dilakukan pada interval waktu 2-3 bulan setelah terakhir pemeriksaan.

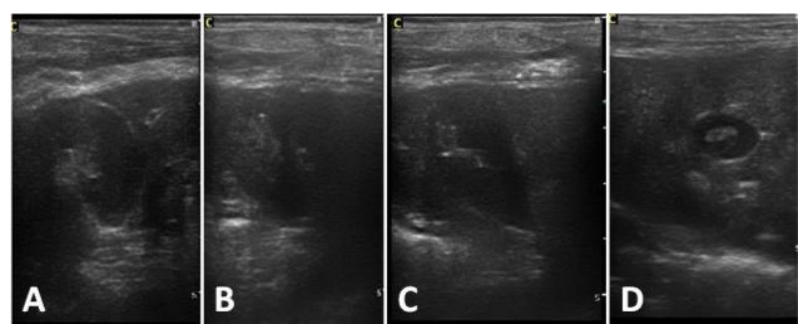

Gambar 1 Sonogram anjing Pomeranian, (A) pemeriksaan awal, (B) hasil evaluasi terapi pertama, (C) hasil evaluasi terapi kedua, (D) hasil evaluasi terapi ketiga.

\section{- HASIL DAN PEMBAHASAN}

Anjing Pomeranian berusia 9 tahun dirujuk ke Rumah

Diterima: 22-12-2019 | Direvisi: 21-01-2020 | Disetujui: 30-01-2020 (C) 2020 CC-BY-SA. Ini adalah artikel Open Access yang didistribusikan berdasarkan ketentuan dari Creative Commons Attribution ShareAlike 4.0 International License (https://creativecommons.org/licenses/by-sa/4.0/). 
Sakit Hewan Pendidikan, Fakultas Kedokteran Hewan, Institut Pertanian Bogor (RSHP FKH IPB) dengan keluhan muntah cairan berwarna kuning disertai pakan. Hasil dari pemeriksaan kimia darah adalah peningkatan kadar alkaline phospatase (ALP) danglutamic pyruvic transaminase (GPT), serta penurunan kadar kreatinin. Nilai ALP merupakan parameter yang sensitif untuk gangguan organ hati Peningkatan nilai ALP menunjukkan adanya kerusakan organ hati atau kantung empedu (Dirksen et al. 2017). Parameter GPT adalah biomarker terjadinya penyakit pada kantung empedu (Whitehead et al. 2016).

Sonogram pada pemeriksaan pertama yang diperoleh adalah organ hati lobus tengah lebih hiperekhoik dan terjadi peningkatan ukuran (Gambar 1). Diagnosis kelainan pada organ hati adalah hepatitis. Permukaan dinding kantung empedu tidak rata dan terdapat massa hipoekhoik menutupi 75\% luas kantung empedu (Tabel 1). Massa pada kantung empedu disebabkan perubahan struktur pada kantung empedu, sehingga terjadi penurunan motilitas dan kemampuan mengeluarkan cairan empedu. Penurunan motilitas membuat epitel kantung empedu terpapar cairan empedu yang bersifat asam dalam waktu yang lama. Berdasarkan hasil pemeriksaan kimia darah dan USG, anjing didiagnosa mengalami cholelithiasis.

Tabel 1 Evaluasi hasil terapi dengan pencitraan ultrasonografi

\begin{tabular}{|c|l|l|l|}
\hline Evaluasi & Waktu & \multicolumn{1}{|c|}{ Terapi } & \multicolumn{1}{c|}{ Hasil pemeriksaan } \\
\hline 1 & $\begin{array}{l}\text { Januari } \\
2018\end{array}$ & $\begin{array}{l}\text { Asam } \\
\text { ursodeoxycholic } \\
\text { dan hepatoprotektan } \\
\text { selama 45 hari }\end{array}$ & $\begin{array}{l}\text { Hati : } \\
\text { Peningkatan ekhogenitas } \\
\text { dan peningkatan ukuran } \\
\text { hati } \\
\text { Kantung Empedu : } \\
\text { Terdapat endapan 75\% }\end{array}$ \\
\hline 2 & $\begin{array}{l}23 \\
\text { Maret } \\
2018\end{array}$ & $\begin{array}{l}\text { Asam } \\
\text { ursodeoxycholic } \\
\text { dan hepatoprotek- } \\
\text { tanselama 45 hari }\end{array}$ & $\begin{array}{l}\text { Hati : } \\
\text { Peningkatan ekhogenitas } \\
\text { pada hati lobus tengah dan } \\
\text { peningkatan ukuran hati } \\
\text { Kantung Empedu : } \\
\text { Terdapat endapan 70\% }\end{array}$ \\
\hline 3 & $\begin{array}{l}\text { Mei } \\
2018\end{array}$ & $\begin{array}{l}\text { Asam } \\
\text { ursodeoxycholic } \\
\text { dan hepatoprotek- } \\
\text { tanselama 45 hari }\end{array}$ & $\begin{array}{l}\text { Hati : } \\
\text { Komogen hipoekhoik } \\
\text { Kantung Empedu : } \\
\text { Terdapat endapan kurang } \\
\text { dari 50\% }\end{array}$ \\
\hline 4 & $\begin{array}{l}14 \\
\text { Agus- } \\
\text { tus } \\
2018\end{array}$ & $\begin{array}{l}\text { Tidak diberikan } \\
\text { terapi }\end{array}$ & $\begin{array}{l}\text { Hati: } \\
\text { Homogen hipoekhoik } \\
\text { Kantung Empedu : } \\
\text { Terdapat endapan } \pm 30 \%\end{array}$ \\
\hline 5 & $\begin{array}{l}\text { Mei } \\
2019\end{array}$ & $\begin{array}{l}\text { Asam } \\
\text { ursodeoxycholic } \\
\text { dan hepatoprotektan } \\
\text { selama 45 hari }\end{array}$ & $\begin{array}{l}\text { Hati : } \\
\text { Komogen hipoekhoik } \\
\text { Terdapat endapan 70\% }\end{array}$ \\
\hline
\end{tabular}

Terapi yang digunakan adalah hepatoprotektan dan asam ursodeoxycholic selama 45 hari dan dilanjutkan evaluasi USG setelah obat habis. Asam ursodeoxycholic adalah asam empedu pada anjing yang bersifat hidrofilik. Sediaan ini diindikasikan untuk hewan yang mengalami penyakit kantung empedu kronis. Mekanisme kerja dari asam ursodeoxycholic adalah menurunkan sitotoksisitas asam empedu dengan menurunkan proporsi asam empedu hidrofobik, menstimulasi sekresi hepatobiliari, dan mencegah apoptosis hepatosit (Copaci et al. 2005). Evaluasi ketiga setelah pemeriksaan awal menunjukkan endapan yang tersisa kurang dai $30 \%$, sehingga terapi dihentikan.

Terapi dihentikan setelah 9 bulan, pasien datang untuk pemeriksaan rutin tanpa adanya keluhan. Hasil evaluasi keempat tidak ada kelainan organ hati. Sonogram kantung empedu menunjukkan dinding kantung empedu tidak rata dan terdapat multiple massa hiperekhoik berukuran $70 \%$ ukuran lumen kantung empedu. Massa hiperekhoik terbentuk kembali dapat disebabkan oleh penurunan motilitas kantung empedu sehingga terjadi penumpukan cairan empedu (Rahmani et al. 2015). Terapi menggunakan asan ursodeoxycholic dan hepatoprotektan kembali dilakukan selama 45 hari.

\section{- SIMPULAN}

Terapi pada gangguan kantung empedu di anjing menggunakan asam ursodeoxycholic dan hepatoprotektan selama 45 hari menunjukkan hasil berupa pengurangan volume endapan di kantung empedu.

\section{- INFORMASI PENULIS}

Penulis untuk Korespondensi *RWA: riliwahyuaji@gmail.com Ilmu Biomedis Hewan, Sekolah Pascasarjana, Institut Pertanian Bogor. Jln Agatis Kampus IPB Dramaga, Bogor, 16680

\section{- UCAPAN TERIMA KASIH}

Penulis berterima kasih atas dukungan dari PT Mega Utama Medica atas fasilitas Q8 Color Doppler Ultrasound di RSHP FKH IPB.

\section{- PUSTAKA ACUAN}

Cook AK, Jambhekar AV, Dylewski AM. 2016. Gallbladder sludge in dogs: ultrasonographic and clinical findings in 200 patients. Journal of American Animal Hospital Association. 52.(3): 125-131.

Copaci I, Micu L, Iliescu L, Voiculescu M. 2005. New therapeutical indication of ursodeoxycholic acid. Romanian Journal of Gastroenterology. 14(3): 259-266.

Dirksen K, Burgener IA, Rothuizen J, van den Ingh TSGAM, Penning LC, Spee B, Fieten H. 2017. Sensitivity and specificity of plasma ALT, ALP, and bile acids for hepatitis in labrador retrievers. Journal of Veterinary Internal Medicine. 31 (4):1017-1027.

Mizutani S, Torisu S, Kaneko Y, Yamamoto S, Fujimoto S, Ong BHE, Niaganobu K. 2017. Retrospective analysis of canine gallbladder contents in biliary sludge and gallbladder mucoceles. Journal of Veterinary Medical Science. 79(2): 366- 374.

Rahmani V, Molazem M, Jamshidi S, Vali Y, Hanifeh M. 2015. Evaluation of gallbladder volume and contraction index with threedimensional ultrasonography in healthy dogs. Journal of Veterinary Medical Science. 77(9): 1157-1161.

Sechi P, Poppi AG, Ilha A, Filho HCK, Lima FES, Garda AB, Gonzales FHD. 2012. Prevalence, risk factors, and biochemical markers in dogswith ultrasound-diagnosed biliary sludge. Research in Veterinary Science. 93 (3): 1185-1189.

Whitehead ML, Kettewell PW, Koterwas BA. 2012. Elevated serum $\gamma$ glutamyltransferase associated with canine renal adenocarcinoma. Veterinary Record.170(14): 362. 